\author{
Karol Miernik \\ http://orcid.org/0000-0003-3092-6894 \\ Uniwersytet Jana Kochanowskiego w Kielcach \\ karolmiernik1994@gmail.com \\ DOI: $10.35765 /$ pk.2021.3504.18
}

\title{
Podstawowe założenia myśli społecznej, politycznej, ekonomicznej i religijnej Ludwika Królikowskiego
}

\section{STRESZCZENIE}

Ludwik Królikowski (1799-1878/81) był polskim publicystą, uczestnikiem powstania listopadowego i działaczem lewicowym doby Wielkiej Emigracji. Głównym zagadnieniem artykułu jest próba odpowiedzi na pytanie, jaki charakter miał światopogląd Królikowskiego w świetle zarówno pozostawionych przez niego tekstów, jak i późniejszej historiografii.

Początki twórczości publicystycznej Królikowskiego sięgają okresu powstania listopadowego. Około 1840 r. zbliżył się do środowiska Gromad Ludu Polskiego, następnie współpracował z francuskim socjalistą utopijnym, Etienne Cabetem. Początkowo sporo miejsca poświęcał sprawie wyzwolenia narodowego Polski. W późniejszym piśmiennictwie na plan pierwszy zdecydowanie wysuwają się zagadnienia wyzwolenia społecznego.

Zwrócono uwagę na szczególne miejsce, jakie w jego piśmiennictwie odgrywało rozumiane w oryginalny sposób chrześcijaństwo. Język, którym się posługiwał, pozostawał pod silnym wpływem tekstów Pisma Świętego, które uważał za najwyższy autorytet $\mathrm{w}$ dziedzinie właściwego ułożenia stosunków społeczno-własnościowych. Jednocześnie trudno jednoznacznie stwierdzić, jaki był jego osobisty stosunek do kwestii transcendencji.

Zasadniczą treścią publikowanych przezeń tekstów była ostra krytyka panujących stosunków własnościowych, które uważał za głęboko niesprawiedliwe. Szczególnie ostro wyrażał się o arystokracji oraz o instytucji papiestwa i rzymskiego katolicyzmu, który w jego mniemaniu odszedł od istoty prawdziwego chrześcijaństwa. Głosił potrzebę zaprowadzenia powszechnej równości prawnej i majątkowej, która doprowadziłaby do powszechnego szczęścia całej ludzkości. Krytyka zastanych stosunków społecznych, politycznych i własnościowych stanowiła główną część jego publicystyki.

SŁOWA KLUCZE: Ludwik Królikowski, Wielka Emigracja, utopia, chrześcijaństwo, socjalizm 


\section{ABSTRACT}

Basic Assumptions of Social, Political, Economic and Religious Thought of Ludwik Królikowski

Ludwik Królikowski (1799-1878/81) was a Polish journalist, participant in the November Uprising, and a left-wing activist during the Great Polish Emigration era. The main issue of the article is an attempt to answer the question about the nature of Królikowski's worldview, in the light of the texts he left behind and the later historiography.

The beginnings of Królikowski's journalistic work date back to the November Uprising. About 1840, he became closer to the community of Gromady Ludu Polskiego, then he collaborated with the French utopian socialist Etienne Cabet. Initially, he devoted a lot of space to the issue of Poland's national liberation. In later literature, the issues of social liberation definitely came to the fore.

The special place in his writings was played by Christianity understood in an original way. The language he used was strongly influenced by the texts of Scripture, which he considered to be the supreme authority in the proper organization of social and property relations. At the same time, it is difficult to say unequivocally what his personal attitude to the issue of transcendence was.

The main content of his texts was a sharp criticism of the prevailing property relations, which he considered deeply unfair. He spoke particularly sharply about the aristocracy and the institution of the papacy and Roman Catholicism, which, in his opinion, departed from the essence of true Christianity. He proclaimed the need to introduce universal legal and property equality that would lead to the universal happiness of all mankind. Criticism of the existing social, political and property relations constituted the main part of his journalism.

KEYW O RD S : Ludwik Królikowski, Great Polish Emigration, utopia, Christianity, socialism

Ludwik Królikowski był jednym z pierwszych - obok Jana Nepomucena Janowskiego, Kazimierza Deczyńskiego i Piotra Ściegiennego (ten ostatni działał w Królestwie Polskim) - działaczy społecznych i politycznych pochodzenia chłopskiego (Janowski, 1950; Deczyński, 1907; Djakow, 1974). Urodzony we wsi Piotrkowice pod Kielcami 24 grudnia 1799 r., dzięki determinacji ojca odebrał elementarne wykształcenie w miejscowym klasztorze oo. Bernardynów, następnie trafił do Szkoły Wydziałowej w Kielcach prowadzonej przez księży bartolomitów. Edukację uwieńczył studiami na Wydziale Prawa Uniwersytetu Warszawskiego, na którym w 1827 r. obronił tytuł magistra administracji (Turowski, 1958). 
W czasie rewolucji listopadowej Królikowski nie uczestniczył bezpośrednio w walce. Toczył ją za pomocą słowa pisanego, poprzez publicystykę umieszczaną na łamach gazet. Po upadku powstania wyemigrował do Krakowa, gdzie założył internat dla młodzieży studiującej na Uniwersytecie Jagiellońskim. W 1839 r. władze krakowskie wydały decyzję nakazującą Królikowskiemu likwidację internatu i opuszczenie miasta. W ten sposób znalazł się we Francji, gdzie mieszkał blisko 40 lat, aktywnie angażując się w spory społeczno-polityczne prowadzone przez różne stronnictwa Wielkiej Emigracji. Pod koniec lat 40. XIX w. nawiązał współpracę ze środowiskiem francuskich socjalistów utopijnych skupionych wokół Etienne Cabeta (Królikowski, 1972).

W podeszłym wieku 79 lat schorowany Królikowski opuścił Paryż i udał się do swojej córki mieszkającej w Stanach Zjednoczonych Ameryki. Zmarł tam w całkowitym zapomnieniu; nie sposób ustalić nawet dokładnej daty zgonu. Ostatnie pismo jego autorstwa to list do rosyjskiego mistyka Korobowa z 1878 r. (Turowski, 1958).

Poglądy Ludwika Królikowskiego na zagadnienia polityczne, ekonomiczne, społeczne i religijne możemy poznawać dzięki pozostawionej przezeń obszernej spuściźnie piśmienniczej. Jej początki sięgają czasów powstania listopadowego i publikowanych wówczas w „Gazecie Polskiej” artykułów. Aktywność twórcza Królikowskiego zakończyła się u schyłku jego życia w końcu lat 70. XIX w. W tym długim, trwającym blisko pół wieku okresie, spod jego pióra wyszło pięć zwartych opracowań książkowych oraz dziesiątki artykułów w licznych czasopismach, głównie emigracyjnych (Kalbarczyk, 1981).

Ostatnio zanegowano funkcjonujący w historiografii pogląd Adama Sikory, jakoby zasadniczy trzon myśli autora „Polski Chrystusowej” „trwał w gotowej, raz na zawsze danej, ostatecznej postaci, nie poddając się upływowi czasu” (Królikowski, 1972, s. 22). Zwrócono uwagę na ewolucję w czasie pewnych wątków myślowych oraz na retoryczny charakter religijnego języka opisu (Kuligowski, 2016). Ta trafna konstatacja pomoże z pewnością łatwiej zrozumieć różne, niekiedy wydawałoby się sprzeczne ze sobą elementy, zawarte w twórczości „polskiego Cabeta”.

Uważa się, że światopogląd Królikowskiego w swoim zasadniczym zrębie ukształtował się ostatecznie w momencie wydania pierwszego zeszytu „Polski Chrystusowej”, a więc około 1842 r. Stwierdzenie to, zasadniczo słuszne, należy uzupełnić o dwa aspekty, w których doszło do zmiany w późniejszej jego twórczości. Pierwszy to stosunek do rewolucji jako środka realizacji założonych celów radykalnej przemiany społecznej. Drugi element to jeszcze silniejsze przesunięcie akcentu ze sprawy wyzwolenia narodowego Polski na ogólne zagadnienie wyzwolenia ludzkości spod panowania błędnego systemu polityczno-gospodarczego (Królikowski, 1972). 
Od samego początku poglądy wyrażane przez Królikowskiego miały radykalny charakter. Punktem wyjścia była dlań krytyka aktualnego porządku społecznego-gospodarczego. Dawał temu wyraz już w publikowanych w czasie powstania listopadowego tekstach. W artykule Podatek osobisty, kontestując obowiązujący układ społeczny, postulował sprawiedliwy - w jego mniemaniu - system opodatkowania, w którym osoby zamożniejsze płaciłyby więcej niż ubożsi utrzymujący się z pracy fizycznej. Z kolei w artykule Nieufność krytykował nieudolność rządów powstańczych, w tym dyktaturę Chłopickiego, i zbytnią uległość oraz naiwność względem caratu rosyjskiego (Kalbarczyk, 1981). W obu tekstach wyraźna jest przede wszystkim krytyka „panów”, a więc górnych warstw społeczeństwa. Głównym zarzutem, jaki formułuje wobec nich Królikowski, jest zaniedbywanie interesów ludu, próżne życie na koszt poddanych i sprzeniewierzenie się zasadom ewangelicznym. Jeszcze nie tak natrętnie jak w późniejszych publikacjach, ale już tutaj autor odwołuje się do Biblii, przedstawiając Chrystusa jako człowieka nakazującego miłość braterską, której nie wcielają w życie warstwy arystokratyczne.

Radykalna myśl polityczna i społeczna Królikowskiego zapewniła mu osobne miejsce w życiu politycznym Wielkiej Emigracji. Gwałtowny atak na arystokrację oraz krytyka własności prywatnej, a także chłopskie pochodzenie - wszystko to ideologicznie najbardziej upodabniało go do radykalnych działaczy Gromad Ludu Polskiego. Po opuszczeniu Rzeczypospolitej Krakowskiej w pierwszych latach pobytu w Paryżu współpracował z Gminą Hawr, publikując w jej organie prasowym, zatytułowanym „Zjednoczenie. Pismo poświęcone zespołecznieniu wszystkich przez wszystkich i dla wszystkich”. Profil społeczny oraz głoszona ideologia Gminy przypominały działalność Gromad Grudziąż i Humań, działających w Wielkiej Brytanii. Doszło do daleko posuniętej współpracy, a nawet próby scalenia obu ugrupowań, co nie podobało się bardziej umiarkowanym działaczom Zjednoczenia Emigracji. Dowodzi to pośrednio, iż poglądy Królikowskiego były bliźniaczo wręcz bliskie ideom głoszonym przez radykalnych emigrantów brytyjskich (Turowski, 1958; Ciołkoszowie, 1966).

Wspomniana powyżej negacja własności prywatnej jako sposobu urządzenia stosunków społeczno-ekonomicznych jest kolejnym, stałym elementem w ideologii Królikowskiego. Punktem wyjścia jest dla niego przekonanie, że wszelkie dobra materialne zostały dane ludziom przez Boga, a zatem każdy rodzaj posiadania indywidualnego jest egoistycznym uderzeniem w moralne, z góry ustalone zasady, przede wszystkim w braterstwo oraz równość. Autor „Polski Chrystusowej” uważał, że własność prywatna zawsze prowadzi do nadużyć, kończąc się poniżającym podziałem na ubogich i bogatych. W pierwszym zeszycie swojego czasopisma pisał o własności, iz jest to „prawo przywłaszczania sobie darów 
Bożych - prawo niszczenia ich i trwonienia, ze szkodą nawet i krzywdą pogrążonych w nędzy Braci”. W dalszej części cytowanego artykułu przekonywał na podstawie Pisma Świętego, że człowiek doskonały powinien wypierać się samego siebie we wszystkich dziedzinach życia, a zatem powinien także wyzbywać się własności „osobniczej” dla dobra społeczeństwa, czy szerzej - całej rodziny ludzkiej. Proponował zatem kolektywną własność ziemi jako jedyną receptę na sprawiedliwe rozwiązanie kwestii chłopskiej (Królikowski, 1842, s. 98-110).

Patrząc na całokształt piśmiennictwa, należy uznać Królikowskiego w głównej mierze za myśliciela społecznego i jednego z prekursorów ideologii polskiego socjalizmu przedmarksistowskiego. Dla Królikowskiego człowiek jest istotą z natury dobrą, natomiast powodem wszelkiej krzywdy i zepsucia są niewłaściwie ułożone stosunki międzyludzkie. Charakterystyczny jest przy tym silnie akcentowany antyindywidualizm. Człowiek nie tylko może, ale powinien żyć we wspólnocie z innymi, gdyż życie społeczne jest uwarunkowane naturalnie. Tylko w społeczeństwie jednostki zyskują na znaczeniu, a zatem życie jednostkowe powinno być całkowicie podporządkowane życiu kolektywnemu. Wolność jednostki w tym ujęciu nie kolidowała z dostosowaniem się jej do kolektywnej egzystencji. Według Królikowskiego tylko życie wspólnotowe może dać każdemu człowiekowi prawdziwe szczęście, a co za tym idzie - prawdziwą wolność. To szczęście i wolność będą wówczas wynikać z poczucia nieśmiertelności, będącej przymiotem jedynie całej ludzkości, która nieustannie trwa, nie zaś pojedynczej osoby, której egzystencja jest ograniczona w czasie (Królikowski, 1842; Missalowa, 1951).

Królikowskiego zalicza się do pierwszego pokolenia polskich socjalistów. Należy jednak pamiętać, iż słowo „socjalizm” w omawianym okresie było pojęciem nowym i rozumiano je na różne sposoby, zazwyczaj jako postawę opozycyjną wobec egoistycznego indywidualizmu. Nie była to jeszcze, jak to się stało później, konkretna propozycja polityczna (Kuligowski, 2012). Dlatego nazywając Królikowskiego myślicielem socjalistycznym, należy przez to rozumieć jego postawę silnie akcentującą nadrzędną wartość kolektywu nad jednostką oraz optowanie za całkowitym zniesieniem własności prywatnej. Chociaż jego pisma, przynajmniej w swojej warstwie retorycznej, dalekie są od marksistowskiego materializmu, to jednak nie bez powodu powojenna historiografia odnajdywała w nim jednego z protoplastów polskich komunistów (Missalowa, 1951). On sam wprost tak się nazwał w jednym z artykułów, określając komunistę następującymi przymiotami: „pełen poświęcenia Patriota, szczery Republikanin, Socjalista, Przyjaciel wszystkich ludzi, prawdziwy Żołnierz Ludu, wierny Uczeń Jezusa Chrystusa” oraz „niestrudzony Apostoł Solidarności” (Królikowski, 1972, s. 596-599). 
Wizja nowego społeczeństwa miała w refleksji Królikowskiego całkowicie utopijny charakter. Wyrażał się on przede wszystkim w abstrahowaniu od zastanych realiów życia społeczno-gospodarczego. Królikowski uznawał się za proroka nowego świata, który miał dopiero nadejść, a który będzie całkowitą negacją świata dotychczasowego, będącego Królestwem Szatana (Królikowski, 1972). Modny w epoce romantyzmu historycyzm oraz idea postępu nie znalazły uznania w formułowanych przezeń poglądach. Historia nie stanowiła źródła inspiracji, była jedynie ciemnym okresem powszechnego błędu. Porównywał ją do trupa, a zajmowanie się nią uważał za zajęcie całkowicie bezużyteczne. Patrząc na dzieje ludzkości, dostrzegał on w zasadzie tylko jeden jasny, inspirujący punkt, mianowicie pierwotne chrześcijaństwo. Epokę teraźniejszą uznawał za czas przełomowy, za bliskie uważał nadejście Królestwa Bożego, przez które rozumiał doskonały ustrój społeczny, pozbawiony wszelkich form ucisku i niesprawiedliwości (Królikowski, 1972).

Niejednoznacznie w historiografii oceniany jest stosunek Królikowskiego do idei postępu. Niesłuszną wydaje się opinia, jakoby jego dorobkiem intelektualnym dla polskiej myśli politycznej XIX stulecia było propagowanie idei ,postępu jako nieuniknionego prawa rozwoju społecznego" (Turowski, 1958, s. 231). W myśli politycznej XIX stulecia idea postępu sprzęgnięta jest zazwyczaj z refleksją historiozoficzną i przekonaniem o ewolucyjnym bądź rewolucyjnym charakterze przemian. Odrzucając rozważania historiozoficzne, Królikowski odrzuca jednocześnie postęp. Zarysowuje bardzo ostro dualistyczną alternatywę, którą najwyraźniej przedstawił w artykule Chrystus i postęp, gdzie pisał m.in., że

pomiędzy Prawdą a błędem, (...) Bogiem a szatanem, Chrystusem a diabłem i carem nie ma i nie może być żadnego środka ani punktu spoczynku. Wszystkie środkowe drogi są drogami błędu, nieprawości i zatracenia (Królikowski, 1972, s. 405).

W przypadku proponowanych przez Królikowskiego rozwiązań mamy zatem do czynienia ze zjawiskiem, które możemy nazwać alternatywą absolutną. Prosty wybór między światem starym a nowym, mię$\mathrm{dzy}$ poparciem interesów arystokracji a interesów ludu, wręcz pomiędzy złem a dobrem, ubrany w szaty religijnego języka, jawi się tutaj jako niezbędna konieczność. Brakuje miejsca na trzecią czy czwartą drogę rozwoju, na akceptację choćby nieco odmiennych wariantów przemian polityczno-społecznych. Królikowski krytykował wszakże nie tylko, co oczywiste, obóz arystokratyczny księcia Adama Jerzego Czartoryskiego, lecz nawet Towarzystwo Demokratyczne Polskie i jego radykalnych działaczy, takich jak Czyński. Paradoksalnie łączył tę krytykę z pragnieniem 
zjednoczenia wszystkich środowisk politycznych Wielkiej Emigracji jako warunkiem niezbędnym do odzyskania suwerenności przez Polskę (Królikowski, 1972).

Kwestia wyzwolenia narodowego Polski pojawia się u Królikowskiego często, lecz jest ona zawsze połączona z problemem wyzwolenia ludu. W tym aspekcie można zaobserwować pewną ewolucję jego poglądów. W okresie powstania listopadowego, pobytu w Krakowie, następnie w czasie pierwszych lat spędzonych na emigracji w Paryżu akcentował nieco silniej wątki narodowe i patriotyczne. Jednakże druga połowa lat 40., a więc okres wydawania „Zbratnienia...” oraz współpracy z francuskimi socjalistami utopijnymi powoduje przesunięcie w akcentach jego twórczości. Zaznaczyła się wówczas silniej ponadnarodowa dążność do uniwersalnej przemiany całej ludzkości. Za ważniejsze od podziałów narodowych uznaje podział na lud i arystokrację (wyzyskiwanych i wyzyskujących), obecny w każdym narodzie. Walka o wyzwolenie ludu jest zatem zadaniem istotniejszym od walki narodowowyzwoleńczej. Według Królikowskiego tylko nowy porządek społeczny może pociągnąć za sobą wybicie się Polski na niepodległość (Turowski, 1958).

Poglądy Królikowskiego należy uznać za utopijne, ponieważ brak w nich konkretnych propozycji organizacji społeczeństwa. Będąc głęboko przekonanym o konieczności budowy całkowicie nowego świata, odcinającego się od przeszłości i teraźniejszości, nie potrafił precyzyjnie określić, kiedy i w jaki sposób rozpocznie się zapowiadana przezeń epoka. Bardzo ogólne idee powszechnej odnowy moralnej i przekazania władzy całkowicie w ręce ludu nie zadowalały czytelników „Polski Chrystusowej”. Toteż w drugim zeszycie tego pisma z 1843 r. Królikowski zaproponował w 120 punktach urządzenie społeczeństwa według ściśle ustalonego porządku, opartego na systemie dziesiętnym. Dziesięć osób miało tworzyć rodzinę, dziesięć rodzin - orszak, dziesięć orszaków - gromadę, dziesięć gromad - gminę, dziesięć gmin - zastęp, dziesięć zastępów - zbór, dziesięć zborów - naród, dziesięć narodów - szczep, dziesięć szczepów wszechwładztwo, czyli ogół ludzkości. Zarówno mężczyźni, jak i kobiety mieli być całkowicie równi w prawach. W tekście przejawiła się anarchistyczna skłonność autora, jako iż wyraził pogląd o zbędnej roli praw pisanych oraz wszelkich form parlamentaryzmu. Władza miałaby się opierać wyłącznie na dwóch zasadniczych przymiotach: na służbie oraz na posłuszeństwie (Królikowski, 1972). Poszczególne komórki społeczeństwa, od najmniejszej do największej, miały wybierać swoich reprezentantów, począwszy od Bogumiła i Bogusława w rodzinie, aż po Wszemiła i Wszewłada, którzy dzierżyliby władzę dyktatorską nad całym zjednoczeniem. Znalazło się miejsce również na armię, nazwaną apostolską, w której służyć mieli wszyscy do tego zdolni, w tym kobiety (Królikowski, 1972). 
Omówiony powyżej artykuł był jedyną próbą precyzyjnego określenia organizacji społecznej nowego, zapowiadanego przez Królikowskiego świata. Należy zauważyć, że próba ta była nieudana ze względu na sztuczny charakter zaproponowanej konstrukcji społeczeństwa. Sam Królikowski porzucił ów projekt, pozostając na poziomie ogólnych nawoływań do przemiany moralnej, odnoszenia się do uczuć i emocji, kontestując wszelkie instytucjonalne formy życia społecznego. W świetle tego artykułu widać również nietypowy stosunek Królikowskiego do idei władzy, którą negował na rzecz dobrowolnej służby społecznej. Posłuszeństwo należy się bowiem wyłącznie Bogu, natomiast wszelkie posłuszeństwo człowieka człowiekowi jest niezgodne z duchem Ewangelii (Królikowski, 1842).

Warto zwrócić uwagę także na fakt, że w przypadku Królikowskiego nie mamy do czynienia z klasyczną utopią. Odrzuca bowiem motyw podróży do idealnego, aczkolwiek odległego świata jako klasyczną konwencję, obecną w utworach Tomasza Morusa czy u bliskiego Królikowskiemu Cabeta, autora Podrózy do Ikarii. Ponadto, w przeciwieństwie do klasycznych utopii, nie uważa się za odkrywcę nowego idealnego ustroju, a jedynie za proroka i apostoła, który przypomniał ludzkości doskonałą propozycję Chrystusa, zapisaną na kartach Ewangelii (Kuligowski, 2015).

Nawoływanie do całkowitej przemiany społecznej, gospodarczej i politycznej było stałym elementem światopoglądu Królikowskiego. Niejednoznaczny był jego stosunek do kwestii środków, jakimi należy walczyć o wprowadzenie w życie tych przemian. W powyższym aspekcie nastąpiła ewolucja jego poglądów. Początkowo poprzestawal jedynie na „apostołowaniu”, czyli pokojowym głoszeniu radykalnych poglądów za pomocą słowa mówionego i drukowanego. Stąd wynikała tak wielka aktywność publicystyczna oraz wydawnicza Królikowskiego, potępienie zaś działalności spiskowej i zbrojnej. Jednakże na łamach ostatniego tomu „Polski Chrystusowej...” w 1846 r. uderzył w ton rewolucyjny, nawołując do walki zbrojnej jako jedynego środka uskuteczniającego nowy układ społeczny. Podobnie uważał w czasie publikacji „Zbratnienia...”, na łamach którego bronił Dembowskiego i chłopów, głosząc pogląd, że winą za rabację galicyjską obciążeni są przede wszystkim arystokraci oraz zaborcze władze austriackie (Królikowski, 1972). Wydarzenia powstania krakowskiego, a następnie Wiosny Ludów miały z pewnością duży wpływ na zmianę stanowiska Królikowskiego do sprawy rewolucji. W każdym razie on sam nigdy nie zaangażował się bezpośrednio w akcję spiskową i rewolucyjną.

W refleksji nad światopoglądem Królikowskiego nie sposób pominąć jego podejścia do zagadnień religijnych. Krytykował nie tylko władzę świecką, uosabianą przez monarchów i arystokratów, ale również władzę duchowną. Główne uderzenie kierował w stronę papieża i Kościoła katolickiego jako instytucji. Chociaż zdobytą edukację zawdzięczał w dużej 
mierze duchownym, nie przeszkodziło mu to zostać jednym z najbardziej zajadłych antyklerykałów w środowisku Wielkiej Emigracji.

Głowę Kościoła Królikowski nazywał „carem rzymskim”, stwierdzając, że jego panowanie nad wiernymi nie różni się niczym od panowania władców nad poddanymi, oparte jest bowiem na przymusie. Prawdziwy Kościół dostrzegał nie w zorganizowanej hierarchicznie instytucji, lecz tam, „gdzie jest zgromadzenie wiernych, społeczność świętych, żyjących (...) w doskonałej między sobą miłości braterskiej, ewangelicznej” (Królikowski, 1842, s. 170-171). W innym miejscu przestrzega przed szkodliwym wpływem „katolictwa”, natomiast papieża określa mianem księcia rzymskiego, zalecając odrzucenie jego zwierzchnictwa (Królikowski, 1972). Silne wątki antyklerykalne wyraził także w dziele Zbawienie Ojczyzny hastem naszym! Stowo z powodu pisma jakiegoś jegomościa, niby Anioła Bożego z Amatei, a rzeczywiście najemnego stuzalca ciemiestwa habsburskiego $w$ Polsce, Bendlikon 1865, w którym zaatakował biskupa krakowskiego Antoniego Junoszę Gałeckiego za potępienie powstania styczniowego i postawę lojalistyczną. Nie szczędził hierarsze ostrych słów, nazywając go bydlakiem i porównując jego postawę do zachowań Heroda, Piłata i Judasza (Królikowski, 1865).

Krytyka Królikowskiego sięga jednakże znacznie głębiej i nie dotyczy jedynie aktualnego stanowiska politycznego papieża Grzegorza XVI czy też zaniedbań ze strony duchowieństwa. Odrzuca on religię w całości, negując ortodoksyjną teologię chrześcijańską, dogmaty czy zasadność wznoszenia świątyń jako miejsc modlitwy. Uważa, że Bóg przemawia do człowieka w głębi duszy, w której można odnaleźć prawdę, prowadzącą następnie do drugiego człowieka w duchu braterstwa (Kalbarczyk, 1981).

Cechą charakterystyczną piśmiennictwa Królikowskiego jest nieustanne odnoszenie się, pośrednio lub bezpośrednio, do tekstów Pisma Świętego. Na cytatach pochodzących ze Starego oraz Nowego Testamentu (przede wszystkim z Ewangelii) i na ich rozważaniu konstruował większość swojej publicystyki. Biblia dostarczała mu argumentów na poparcie wielu stawianych przez siebie tez. Należy stwierdzić, że przypisywał jej zbyt wielkie znaczenie, traktując jako podręcznik życia społecznego i ekonomicznego. Królikowski połączył zatem w sposób wielce oryginalny radykalne postulaty społeczne $\mathrm{z}$ językiem o religijnym zabarwieniu. W ten sposób w jego tekstach dokonało się zjawisko, które możemy nazwać aktualizacją Pisma Świętego. Wyrywając niejednokrotnie teksty biblijne $z$ ich naturalnego kontekstu, zastosował je do różnych dziedzin życia, jak najdalszych od religii. Odwołując się do nich nieustannie jako do najwyższego autorytetu, jednocześnie podważał tenże autorytet, odbierając Ewangelii jej właściwy, sakralny charakter (Turowski, 1958). 
Kwestią nierozstrzygniętą pozostaje, dlaczego Królikowski zastosował tego rodzaju archaiczny, religijny język do wyrażenia rewolucyjnych i w istocie antyreligijnych poglądów. Prawdopodobnie był przekonany, że radykalna doktryna społeczna stanie się bardziej przekonująca w szacie sformułowań biblijnych. Istnieje również pogląd, że język opisu przezeń użyty, silnie metaforyczny, miał jedynie retoryczny charakter i stał się metaforą absolutną, to znaczy, że sam język wpływał na sposób organizowania wyrażanych myśli (Kuligowski, 2016). Analizując liczne teksty Królikowskiego z różnych okresów życia, nasuwa się przede wszystkim konstatacja, że wierzył autentycznie w doczesny (i tylko doczesny) sens zasad ewangelicznych. Dowodzi tego żarliwość głoszonych poglądów, częstotliwość i energiczność, z jaką tworzył kolejne pisma, oraz fakt, że we wszystkich dziełach odnaleźć można tę samą, gorącą życzliwość dla sprawy wyzwolenia ludu w połączeniu z niechęcią czy wręcz nienawiścią do arystokracji. Chociaż nie udało mu się zrealizować wielu zaplanowanych przedsięwzięć oraz przekonać do swoich pomysłów szerszego grona emigrantów, pozostał niewzruszony w sformułowanych poglądach, będąc dalekim od próby jakiejkolwiek rewizji własnej doktryny.

Podsumowując, myśl Ludwika Królikowskiego stanowiła oryginalny wkład w życie intelektualne Wielkiej Emigracji. W krytyce górnych warstw społecznych zawarł wiele trafnych spostrzeżeń, zwracając uwagę na takie problemy, jak polityczne i ekonomiczne upośledzenie chłopów czy obojętny stosunek części arystokratów wobec konieczności reform. Obok działaczy Gromad Ludu Polskiego był on najbardziej radykalny, jeśli chodzi o wysuwane postulaty. Jako jeden z pierwszych głosił potrzebę całkowitego zniesienia różnic klasowych (Turowski, 1958). Jego pisma stanowią ciekawą fuzję skrajnie radykalnych poglądów i kaznodziejskiego języka. Nietypowe rozumienie religii i biblijny charakter jego tekstów od dawna zajmuje badaczy, stwarzając trudności w jednoznacznym sklasyfikowaniu jego myśli. Przez jednych był uważany za filozofa religijnego i mesjanistę, przez innych wprost przeciwnie - za myśliciela antyreligijnego i ukrytego ateistę. Dowodzi to, iż jego dorobek intelektualny nie poddaje się prostej kategoryzacji, co w sumie stanowi zaletę, pozostawia bowiem wiele otwartych pytań badawczych (Kuligowski, 2016). 


\section{Bibliografia}

Ciołkoszowie, L. i A. (1966). Zarys dziejów socjalizmu polskiego. T. 1. Londyn: Gryf. Publications Ltd.

Deczyński, K. (1907). Żywot chtopa polskiego na początku XIX stulecia. Warszawa, Lwów: Nakład J. Mortkowicza.

Djakow, W. (1974). Piotr Ściegienny. Ksiądz-rewolucjonista. Warszawa: Książka i Wiedza.

Janowski, J.N. (1950). Notatki autobiograficzne. Wrocław: Zakład Narodowy im. Ossolińskich.

Jedlicki, J. (1988). Jakiej cywilizacji Polacy potrzebują? Studia z dziejów idei i wyobrazni XIX wieku. Warszawa: Państwowe Wydawnictwo Naukowe.

Kalbarczyk, D. (red.). (1981). Wskrzesić Polske, zbawić swiat. Antologia polskiej chrześcijańskiej mysli spoteczno-radykalnej 1831-1864. Warszawa: Instytut Wydawniczy Pax.

Królikowski, L. (1840). Westchnienie pobozine za dynastya Czartoryskich w Polsce, przestane z ziemi ucisku do synów jej w rozproszeniu. Paryż: P. Baudouin.

Królikowski, L. (1842). „Polska Chrystusowa: Pismo poświęcone zasadom spółecznym, wydawane staraniem Ludwika Królikowskiego” T. 1, z. 1.

Królikowski, L. (1862). Pochwata Rodu Gesiego, wypowiedziana przed obliczem Bozym ku przestrodze $i$ zbudowaniu braci szukajacych zbawienia wiecznego swojej Ojczyzny. Paryż: Drukarnia L. Martinet.

Królikowski, L. (1865). Zbawienie Ojczyzny hastem naszym! Stowo z powodu pisma jakiegośjegomościa, niby Aniota Bożego z Amatei, a rzeczywiście najemnego stuzalca ciemięstwa habsburskiego w Polsce. Bendlikon: Drukarnia Dziennika Ojczyzny,

Królikowski, L. (1972). Wybór pism. Warszawa: Książka i Wiedza.

Kuligowski, P. (2012). Miecz Chrystusa. Chrześcijańskie inspiracje polskiego socjalizmu sprzed powstania styczniowego. Ogrody Nauk $i$ Sztuk, nr 2, 50-61.

Kuligowski, P. (2015). Królestwo Boże na ziemi: wokół sporu Ludwika Królikowskiego i Jana Czyńskiego. Historia Slavorum Occidentis, 1(8), 77-93.

Kuligowski, P. (2016). Retoryka i utopia. Ludwik Królikowski: studium struktury myśli. Klio. Czasopismo poświęcone dziejom Polski i powszechnym, t. 37, 2, 101-124.

Limanowski, B. (1890). Historya ruchu społecznego w XIX. Stuleciu. Lwów: Księgarnia Polska.

Missalowa, G. (1951). Francuski socjalizm utopijny i jego wpływ na polską myśl rewolucyjną w latach 1830-1848. W N. Gąsiorowska (red.), W stulecie Wiosny Ludów 1848-1948. T. 3, Wiosna Ludów w Europie, cz. 2., zagadnienia ideologiczne. Warszawa: Państwowy Instytut Wydawniczy, 7-162.

Turowski, J. (1958). Utopia spoteczna Ludwika Królikowskiego. Warszawa: Instytut Wydawniczy Pax. 
Ziółek, J. (1994). Ze studiów nad życiem religijnym Wielkiej Emigracji. Studia polonijne. T. 16.

Karol Miernik - absolwent historii na Uniwersytecie Jana Kochanowskiego w Kielcach oraz na Katolickim Uniwersytecie Lubelskim, archiwista, kolekcjoner pamiątek przeszłości. Jego zainteresowania naukowe oscylują wokół dziejów idei w XIX stuleciu. 